\title{
Gus Miek's Suluk Jalan Terabas: An Approach on the Accountability of Islamic Organisation
}

\author{
Januar Eko Prasetio ${ }^{1}$, Iwan Triyuwono ${ }^{2}$, Eko Ganis Sukoharsono ${ }^{2}$, Lilik Purwanti ${ }^{2}$ \\ \{januar_ep@upnyk.ac.id ${ }^{1}$, iwant@ub.ac.id², ekoganis@ub.ac.id², lilik@ub.ac.id²\} \\ ${ }^{1} \mathrm{PhD}$ Student, Faculty of Economics and Business, Brawijaya University, Malang, Indonesia \\ ${ }^{2}$ Department of Accounting, Faculty of Economics and Business, Brawijaya University, Malang, \\ Indonesia
}

\begin{abstract}
Challenges arise in understanding the concept of accountability in religious organisations because religious organisation tends to promote their sacred missions more than implementing formal accountability rules such as in the commercial and public sector. Religious organisations more focus on their belief values than commercial structures, and produce formats that are not fully compatible with formal financial reporting. The purpose of this paper is to introduce the concept of accountability applied in the Qur'an recitation and Dzikrul Ghofilin community through the Suluk Jalan Terabas method as proposed by Gus Miek. The results show that the Gus Miek's Suluk Jalan Terabas act as an approach of accountability implementation and can be fulfilled if it is embedded in daily practice and habit of their member, which is always tafakkur, tasyakkur, and tadzakkur.
\end{abstract}

Keywords: accountability, Islamic organisation, Suluk Jalan Terabas.

\section{Introduction}

Religions and religious organizations shared challenges in understanding the accountability [1]. Religious organizations tend to promote sacred missions rather than complying with the accountability rules like those in commercial and public sectors. They are likely to focus on faith and values rather than commercial structure $[1,2]$ and provide accounts that are not fully comply with formal reports [3].

In 2006, Jayasinghe reported the accountability practices in Buddhist and Hindu religious organizations in non-western societies [4]. Religious institutions, such as temples, play an important role in their society, especially in regulating social and political practices [5]. What commonly inseparable from religiosity are Allah, eternity, reincarnation as well as mutual dependence, closeness to temples and the imams. On the contrary, Western societies are largely dominated by Protestant work ethics and rational lifestyles, lacking in financial understanding, and having emotional imperative and power relations, as well as making rational substantive calculations in their daily lives $[4,6]$.

The literatures focusing on accounting and accountability of religious organizations in Western society have focused around Christian denominations, except studies reported by Abdul-Rahman and Goddard [7] and Bowrin [8]. Majority of studies on Christian denominations put emphasis on technical and functional accounting rather than providing interpretive analysis on how such accounting practices interact with religious faith [9-15]. 
Meanwhile, the theoretical approaches employed in the majority of post-1980 studies have been dominated by religion rather than secular divide which focus on the perceived "incompatibility" between religious belief systems and the use of accounting practices and official accountability in churches [16-18].

There is a request to use alternative models of articulation analysis as a way to conceptualize the role of accounting practice and accountability in religious organizations [1921]. Hardy and Ballis (2005) argue that accounting studies in the context of religion can be improved by seeking to better understand the internal and external social belief systems [20]. Gallhofer and Haslam (2004) also urge accounting researchers to consider theological lessons with a view to making accounting concepts as an instrument of emancipation favouring grassroots struggle rather than as an instrument of capitalist oppression [19].

The debate in the literatures focused on determining and interpreting accountability [22], and developing accountability mechanisms, principles and frameworks for non-profit organizations [23-27]. Accounting researchers initially explored the extent to which accounting systems and accounting practices were used in the religious settings of the dominant functional mindset and in the modernization of financial accountability systems [815].

Concerning the sacred unique environment that defies rational proof and calculation $[17$, 28 ] and one that is supposedly characterized as being theoretically extreme and dominated by non-financial ideology [29], many researchers studied on how accounting is actually interacts with religious beliefs. However, debates and discussions of the "sacred rather than secular" application have become interesting subjects as reported in many papers [7, 17, 18, 20, 21, 3034].

Particularly in Java, Indonesia, there is an Islamic community that develop progressively and practice accountability in a unique way, which is Jantiko Mantab founded by Kyai Haji Chamin T. Djazuli (Gus Miek) in 1970s with two main public activities, namely semaan AlQur'an and Dzikrul Ghofilin. Gus Miek is a murshid ${ }^{1}$ [35] and the only person in charge in the first stage of semaan Al-Qur'an and Dzikrul Ghofilin. Semaan Al-Qur'an is more or less similar to other religious activities. The religious practice constituting the semaan Al-Qur'an is not a special ritual less known by the community. It includes five time congregational prayers, reciting or listening to the Quran, dzikr, tahlil and shalawat. The uniqueness of accountability approach shown by this organisation is discussed in this paper. Gus Miek's Suluk Jalan Terabas conceptual framework implemented in communal semaan Al Qur'an and Dzikrul Ghofilin is also explored.

\footnotetext{
${ }^{1}$ A Murshid has a considerable responsibility because he has a number of requirements that include: First, he must be pious and expert to guide his students in fiqh and tawheed with knowledge that rule out any prejudices and doubts in the mind of his students on that matter. Second, being wise with all the qualities of the perfection of the heart, civilized, and aware of all the anxieties of the soul and its illness and know how to nourish and improve it. Third, having affection for Muslims especially for his students, being patience and merciful, and never getting bored to provide advices. Fourth, adept at keeping the secret of his disciples, or not to expose their ignominy, but to always keep an eye with his sharp Sufi vision and to improve them very wisely. Fifth, never betray his disciples' mandate, never use the property of his disciples and never want their property. Sixth, never ask his disciples to do anything other than to carry out proper commands. Seventh, never hanging out too much with, and telling too much jokes to, his disciples. Eighth, to keep all his words clean from any bad influences of his passion and desire, especially those that leaves undesired marks for the rest of his disciples' life. Ninth, to always be open minded and sincere, not expecting praises and flatteries, never burdening his disciples with either thing they could not do or interested in. Always generous in teaching and in other matters [35].
} 


\section{Research Method}

This research is a case study of a spiritualist, a research method that specifically investigates contemporary phenomena contained in a real-life context, implemented when the boundaries between phenomena and the context are unclear, using multiple data sources, including direct observation and literature review, seeking to establish the concept of accountability from Gus Miek's attachment to Allah SWT. The method of Suluk Jalan Terabas bring authors to conduct research that can understand the phenomenon of what is experienced by research subjects such as behaviour, perception, motivation, action, taste, and situation comprehensively and with description in the form of words and language in a special context that is natural and through various scientific methods.

\section{Result and Discussion}

Spiritual paradigm is a paradigm that emphasizes the integrity of reality [36]. This paradigm brings the researcher into a unity with the reality researched with God as the center of reality. The study of the spiritual paradigm seeks to relate science to the spiritual values that other paradigms cannot. The spiritualist paradigm produces a spiritualist research design based on spiritual spontaneity [36]. Spiritual spontaneity is a spiritual experience between a person and the environment and God.

Spirituality and accounting can be reached through theological analysis, rather than being articulated mainly from secular and sociological point of view [19, 32, 37]. Currently, few researchers studied the characteristics of accountability and practices in the context of Islamic religious organisations comprehensively $[31,32,38]$, because the majority of studies focuses on the Christian tradition. For example, Berry's (2005) studies on the Church of England provide some insight into accountability in Christianity based on the Western context [38].

To the best of authors knowledge, there is no indication or split between material and spiritual since IONA teaches that one's spirituality is rooted in the reality of everyday life and in the life of one's faith. Jacobs and Walker (2004) also observed that socialization of types of accountability may not necessarily be positive and can also serve as a structure for internal dominance and control [31]. In addition, the study by Kreander et al. (2004) demonstrates the practice of religious organizations which unifies the spirituality and theology [32].

In the study of accounting and accountability in Islamic organisations, the issues mentioned above are also referred to by Abdul-Rahman and Goddard's study [7]. The world view of Islam encompasses both the mundane and the religious aspects. The mundane aspect must be related, in a profound and inseparable way, to the religious aspect without ignoring former. Arising from the central concept of Tawhid (Oneness of God), Islam has developed its own concept of accountability, in which everyone is obliged to accept all duties and obligations and benefits of any ownership or responsibility entrusted to them and this will be judged on Judgment Day.

In contrast to traditional concepts and limitations of accountability, they argue that accountability has two interrelated and universal aspects of history. The role of formal accounting and accountability in religious settings can be conceptualized by certain religious teachings or beliefs. Irvine (2005) argues that "different denominations, like organizations, will have different views on whether accounting is compatible with their religious beliefs" [33].

Although Islam does not provide an explicit comprehensive theory in accounting, it still provides a set of general guidelines that can be applied to achieve the primary goals of management that are not fundamental to materialism [39]. The general guidelines of Islam are 
based on the concepts of human welfare and good living, brotherhood and socio-economic justice, as well as a balanced satisfaction of the material and spiritual needs of all human beings [40]. Islam provides the most comprehensive understanding of leadership through a highly developed and modern ethical system based on the Qur'an, and hadiths of the Prophet Muhammad SAW [41]. Islam provides comprehensive guidance in all aspects of life-namely religious, moral, ethical, socio-cultural, economic, political, or legal matter-to lay a strong foundation of Islamic society, built on surrender to the will of Allah and the teachings of Prophet Muhammad SAW [41, 42].

\subsection{Suluk Jalan Terabas}

What is Suluk? What is Jalan Terabas? What does Suluk Jalan Terabas means? Suluk is usually understood as an attempt or endeavor of a person to gain a makrifat of Allah SWT and to draw closer to Allah SWT, actualized in the manner prescribed by God and His apostle [43]. The Jalan Terabas simply means the shortcut pass among the many paths to reach the destination. Suluk Jalan Terabas represents the framework developed by Gus Miek that serves as guidelines in determining the fastest and accurate steps to reach the destination.

Suluk Jalan Terabas has been developed by Gus Miek as an alternative way to solve problems and/or to reach goals because the existing regular paths are no longer sufficient to achieve the goals. Moreover, the existing ways may take longer time and are difficult to implement for some people. Suluk Jalan Terabas represents a path to take when various other ways are no longer possible to apply. However, Suluk Jalan Terabas is not the ultimate choice after making reasonable efforts. It is the easiest option for achieving the goal. It allows every person from all walks of life to have an equal opportunity for achieving common religious goals. The framework of Jalan Terabas as practiced by Gus Miek in the course of his life deals with: (a) preparing for life, struggle and endeavour to be great; (b) the santri or seekers of religious knowledge; (c) guiding the Muslims; (d) disobedience; (e) meeting necessities of life; (f) jamiyah or religious congregation; and (g) politics.

\subsection{The Conceptual Framework of Jalan Terabas}

In Jalan Terabas conceptual framework, the complexity of implementation depends on the scale of the objectives to be achieved in consideration of the existing capital [43]. Similarly, the appropriateness of its application is highly dependent on boils down to a person's ability to define the conceptual framework when he is going to complete the program. In the same case, it is possible to find many different paths to follow through, since differences also exist in determining the potentials within the conceptual framework. Likewise, the path a person chooses to follow will depend on his ability to determine which one is best suited for him or her.

There are five basic principles to be mastered by every person who wishes to apply this Jalan Terabas conceptual framework. They are inseparable from one another, and are mutually influential and determining each other. The five principles are as follows: (a) ability to realize self-potentials that include property, heredity, religion, and personality; (b) the importance of understanding the purposes of getting into heaven, achieving position and greatness, and pursuing science; (c) ability to recognize the potentials of subjects that include God, people, books and teachers; (d) ability to recognize the potentials of worship, Islamic preaching, and science; and (e) preparedness and courage to take risks. 


\subsection{Suluk Jalan Terabas as a Spiritual Accountability in Semaan Al Qur'an}

What makes semaan al Qur'an looks different is the "masterly touch" of Gus Miek as reflected and realized in its mission and presentation. First, through his semaan Al Qur'an, Gus Miek invites his entire congregation to learn to be attentive and to believe in things that are supposed to be very important and to be believed in. The things that are very important that concerns the hereafter have received less attention. They consist of five time prayers held in congregation and efforts to familiarize oneself with the Qur'an. Through semaan Al Qur'an, Gus Miek pleads his congregation to return to the correct perspective. Preparation of the right priority scale in everyday life is necessary to gradually improve the quality of life and to bring peace and tranquillity.

Secondly, not only focusing on outward worship, Gus Miek also organise and guide all people that involved in semaan Al Qur'an to be more appreciate and dig deeper into the outward worships and not to get stuck in such routines. Through this collective ritual, by selective interaction among those taking part in this activity, Gus Miek taught the standard "moral values". The values of humanity and servanthood are necessary to achieve the predicate as both a human being and a servant, to deserve to be called as "man" and "servant of Allah" or Abdillah.

Broadly speaking, Gus Miek's idea of semaan Al Qur'an is about how to organize such ritual of Islamic spirituality in a safe, orderly, neat, responsible, and humane way. Gus Miek presents his principles of its implementation as the following guidelines: (1) all those involved must be eager to be sincere. Eager to really purify their heart and to focus on Allah; (2) It is necessary to appear sympathetic and attractive. All who are involved in this ritual must be polite, inward. This is because it involves many people and interaction with others; (3) the implementation should be simple yet valuable. Focus on worship and avoid too much use of "accessories" that potentially divert our intention from the right direction.

Concerning the sincerity, Gus Miek invites all those participating in semaan al Qur'an to be prepared both inwardly and outwardly, by determining the only intention to worship, to learn zuhud and kholwah. Gus Miek put emphasis on avoiding the condition where those who invite and those being invited share the focus of attention simply and principally on material ("al-jarru wal majruru muta'alliqun bil fulus").

Gus Miek provides guidance to the person who memorize the Qur'an (hafiz) to be selfindependent, to prepare for everything they need to attend semaan Al Qur'an, including transportation and accommodation. By doing so, their participation in that forum is truly for the purpose of worship, without expecting anything in return, especially from the host. Gus Miek believes that the factor that will make this forum to gain the good pleasure of Allah is the persistence and resilience of all those involved in seeking to sincerely do this only for Allah's sake.

Those who are trusted to organize the worshipers are expected to have servanthood who is ready to provide service without demanding to be served. In everyday language, Gus Miek elucidated a hadith of the Prophet Muhammad SAW: "A'dhomun nasi ajran khodimuhum -The greatest of rewards are reserved only for those who are ready to serve others". This means that anyone who is ready to become "servant" of others, the gate of heaven will be opened for him. If a person does not have such a mentality, it will be better for him or her to compensate this by performing efficacious prayer and bringing benefit to society. If the person does not have even one of these, then it is better for him or her to resign from this forum.

Furthermore, Gus Miek abhorred arrogant individual, let alone group, because it makes a person to act toward others in an arbitrary way. Gus Miek also disliked any form of violation, either minor or major ones. To the congregation members, Gus Miek invites them to become 
good citizens. As for the orderliness and safety, he also advised congregation members to uphold the "dignity" of semaan Al Qur'an. Do not let it to be tainted by miss-behaviours.

The concept of simplicity that becomes the "standard" and fundamental value in every event of semaan Al Qur'an aims to make this event to be held in a simple yet valuable way, rather than burdensome to anyone, and to put priority on togetherness and mutual cooperation. It is necessary to keep it orderly and humane. All attendants should be persuaded and invited to take part in accordance with the opportunity and the capability at their disposal, without feeling compelled to do so. The act of force is not permitted, albeit in a subtle way. This can cause people to take part in the semaan Al Qur'an's with feelings of being coerced, rather than sincerely. Anyone entrusted with the mandate of the people shall carry out the mandate responsibly and appropriately, in accordance with the purpose of it. The event should be held modestly, focusing only on a valuable ritual of worship.

\subsection{Suluk Jalan Terabas as a Spiritual Accountability in Dzikrul Ghofilin}

Dzikrul Ghofilin is an Islamic spiritual litany aimed at achieving eternal life in the hereafter. It is not intended to gain direct success in this world. Therefore, it is haram or forbidden, to promote such spiritual event in regards to gain worldly benefit.

The principal purposes of the Dzikrul Ghofilin practice are: (1) to gain Allah's approval in every effort to obey His commands and to avoid what He prohibited, despite our limitations and shortcomings; (2) to get the mahabbah (love) and syafaah (intercession) of the Prophet Muhammad SAW, as well as the syafaah of auliya and sholihin; (3) to gain the blessings and mercy of Allah; and (4) to gain Allah's blessings of a beautiful life and husnul khotimah (a good ending).

The signs that Dzikrul Ghofilin had been practiced appropriately and began to show results--as was the case for semaan Al Qur'an, according to Gus Miek--are the linkage and the unity of both, provided that the practitioners have virtuous habits of practicing the tafakkur, tasyakkur, and tadzakkur.

Tafakkur is, in essence, practiced to do self-correction on a continual basis so as not to have time to see the mistakes of others. This allows a person to come to realize that he or she is the servant of Allah that is weak, sinful and still far from being virtuous, rather than the other way around. Tasyakkur is basically one's effort to discover and appreciate that all the provisions of Allah will apply to his life, both for joy and for sorrow. It is meant for a person to realize that all these are the manifestations of God's love and grace to him, and to have positive thought of Allah's providence. Tadzakkur is realized through your remembrance of Allah; that Allah is with you and watching you in every move and silence. If you have not achieved any of these, it does not necessarily mean that you practiced it the wrong way, but it could be that you lack confidence in what you have practiced, or you did this less sincerely and consistently.

\section{Conclusion}

The concept of accountability found in the semaan Al Qur'an and Dzikrul Ghofilin of Jantiko Mantab is different from other religious organisations. Through understanding and implementing Suluk Jalan Terabas, the concept of accountability that is reflected in these activities can be fulfilled if the congregation's daily practice and habit is embedded with tafakkur, tasyakkur, and tadzakkur. This also shows that Gus Miek's approach on accountability of his movement or organisation creates humanitarian values and servitude that 
are needed to be able to achieve the title of being a human being and a servant, so that they deserve to be called both as "human" and as "servants of God".

\section{References}

[1] Cadge, W. and Wuthnow, R. in Powell, W.W. and Steinberg, R. (Eds), The Non-Profit Sector - A Research Handbook, Yale University Press, New Haven, CT, pp. 485-505 (2006).

[2] Clemens, E.S. The constitution of citizens: political theories of nonprofit organisations, in Powell, W.W. and Steinberg, R. (Eds), The Non-profit Sector - A Research Handbook, 2nd ed., Yale University Press, New Haven, CT, pp. 207-220 (2006).

[3] Rose-Ackerman, S. Altruism, nonprofits, and economic theory, Journal of Economic Literature, Vol. 34, pp. 701-728 (1996).

[4] Jayasinghe, K. Micro-entrepreneurship in a rural community of Sri Lanka: a phenomenological study of emotionality, power and calculative practice, PhD Thesis, University of Bradford, Bradford (2006).

[5] Nelson, J.K. The Anthropology of Religion: A Field Statement for the Department of Anthropology, University of California, Berkeley, USA (1990).

[6] Northcott, D. and Doolin, B. Home accountants: exploring their practices, Accounting, Auditing \& Accountability Journal, Vol. 13 No. 4, pp. 475-501 (2000).

[7] Abdul-Rahman, A.R. and Goddard, A. An interpretive inquiry of accounting practices in religious organisations, Financial Accountability \& Management, Vol. 14 No. 3, pp. 183-201 (1998).

[8] Bowrin, A.R. Internal control in Trinidad and Tobago religious organizations, Accounting, Auditing \& Accountability Journal, Vol. 17 No. 1, pp. 121-152 (2004).

[9] Futcher, T. and Phillips, J.T. Church budgeting: a secular approach, National Public Accountant, Vol. 32 No. 9, pp. 28-29 (1986).

[10] Kreiser, L. and Dare, P. Shaker accounting records at Pleasant Hill: 1830-1850, The Accounting Historians Journal, Vol. 13 No. 2, pp. 19-36 (1986).

[11] Swanson, G. and Gardner, J. The inception and evolution of financial reporting in the Protestant Episcopal Church in the United States of America, The Accounting Historians Journal, Vol. 13 No. 2, pp. 55-63 (1986).

[12] Swanson, G. and Gardner, J. Not-for-profit accounting and auditing in the early eighteenth century: some archival evidence, The Accounting Review, Vol. 63 No. 3, pp. 436-447 (1988).

[13] King, A. Automating church accounting, Management Accounting (US), March, pp. 18-20 (1988).

[14] Faircloth, A. The importance of accounting to the shaker, The Accounting Historians Journal, Vol. 15 No. 2, pp. 99-129 (1988).

[15] Zietlow, J.T. Capital and operating budgeting practices in pure non-profit organizations, Financial Accountability \& Management, Vol. 5 No. 4, pp. 219-232 (1989).

[16] Laughlin, R.C. The design of accounting systems: a general theory with an empirical study of the Church of England, unpublished $\mathrm{PhD}$ thesis, University of Sheffield, Sheffield (1984).

[17] Laughlin, R.C. Accounting in its social context: an analysis of the accounting systems of the Church of England, Accounting, Auditing \& Accountability Journal, Vol. 1 No. 2, pp. 19-42 (1988). 
[18] Booth, P. Accounting in churches: a research framework and agenda, Accounting. Auditing \& Accountability Journal, Vol. 6 No. 4, pp. 37-67 (1993).

[19] Gallhofer, S. and Haslam, J. Accounting and liberation theology: some insights for the project of emancipatory accounting, Accounting, Auditing \& Accountability Journal, Vol. 17 No. 3, pp. 382-407 (2004).

[20] Hardy, L. and Ballis, H. Does one size fit all? The sacred and secular divide revisited with insights from Niebuhr's typology of social action, Accounting, Auditing \& Accountability Journal, Vol. 18 No. 2, pp. 238-254 (2005).

[21] McPhail, K., Gorringe, T. and Gray, R. Crossing the great divide: critiquing the sacred secular dichotomy in accounting research, Accounting, Auditing \& Accountability Journal, Vol. 18 No. 2, pp. 185-188 (2005).

[22] Sinclair, A. The chameleon of accountability: forms and discourses, Accounting. Organizations and Society, Vol. 20 No. 2-3, pp. 219-237 (1995).

[23] Fry, R.E. Accountability in organizational life: problem or opportunity for non-profits? Non-profit Management and Leadership, Vol. 6 No. 2, pp. 181-195 (1995).

[24] Jordan, L. Mechanisms for NGO accountability, Global Public Policy Institute (GPPi) Research Paper Series, No. 3, Global Public Policy Institute, Berlin (2005).

[25] Goddard, A.R. Budgeting practices and accountability habitus - a grounded theory, Accounting, Auditing \& Accountability Journal, Vol. 17 No. 4, pp. 543-577 (2004).

[26] Dixon, R., Ritchie, J. and Siwale, J. Microfinance: accountability from the grassroots, Accounting, Auditing \& Accountability Journal, Vol. 19 No. 3, pp. $405-427$ (2006).

[27] Gray, R., Jan Bebbington, and David Collison. NGOs, Civil Society and Accountability: Making the People Accountable to Capital. Accounting, Auditing, and Accountability Journal. Vol. 19, No.31. pp. 319-348 (2006).

[28] Morgan, G. Organizations in Society, Macmillan, London (1990).

[29] Lightbody, M. On being a financial manager in a church organisation: understanding the experience, Financial Accountability \& Management, Vol. 19 No. 2, pp. 117-138 (2003).

[30] Kluvers, R. Budgeting in Catholic parishes: an exploratory study, Financial Accountability \& Management, Vol. 17 No. 1, pp. 41-58 (2001).

[31] Jacobs, K. and Walker, S.P. Accounting and accountability in the Iona community, Accounting, Auditing \& Accountability Journal, Vol. 17 No. 3, pp. 361-381 (2004).

[32] Kreander, N., McPhail, K. and Molyneaux, D. God's fund managers: a critical study of stock market investment practices of the Church of England and UK Methodists, Accounting, Auditing \& Accountability Journal, Vol. 17 No. 3, pp. 408-441 (2004).

[33] Irvine, H. Balancing Money and Mission in A Local Church Budget. School of Accounting and Finance, University of Wollongong. Australia. Research Article. (2005).

[34] Jacob, K. The Sacred and The Seculer: Examining the Role of Accounting In The Relegius Context. Departement Of Accounting and Management, School of Business. La Trobe University, Melbourne, Australia. Research Article. Vol. 18, No 2 (2005).

[35] Aceh, A.B. Pengantar Sejarah Sufi dan Tasawuf. CV. Ramadhani, Solo (1987).

[36] Triyuwono, I. [Makrifat] Metode Penelitian Kualitatif [dan Kuantitatif] Untuk Pengembangan Disiplin Akuntansi. Simposium Nasional Akuntansi ke16 di Manado pada tanggal 25 - 27 September (2013).

[37] McPhail, K., Gorringe, T. and Gray, R. Accounting and theology, an introduction: initiating a dialogue between immediacy and eternity, Accounting, Auditing \& Accountability Journal, Vol. 17 No. 3, pp. 320-326 (2004). 
[38] Berry, A.J. Accountability and control in a cat's cradle, Accounting, Auditing \& Accountability Journal, Vol. 18 No. 2, pp. 255-297 (2005).

[39] Abuznaid, S. Islam and Management: What Can Be Learned? Thunderbird International Business Review, Vol. 48, pp. 125-139 (2006).

[40] Chapra, M.U. Islam and the Economic Challenge. International Institute of Islamic Thought, Herndon, VA. USA (1992).

[41] Toor, S.R. An Islamic Leadership Theory: Exploring the Extra Dimensions. Proceeding of the International Conference on Management from Islamic Perspectives (ICMIP), May 15-16, Kuala Lumpur, Malaysia (2007).

[42] Beik, I.S. and Arsyianti, L.D. Islamic Paradigm on Leadership and Management: A Conceptual Analysis. Proceeding of the International Conference on Management from Islamic Perspectives (ICMIP), May 15-16, Kuala Lumpur, Malaysia (2007).

[43] Ibad, M. N. Suluk Jalan Terabas Gus Miek. Pustaka Pesantren Yogyakarta (2007). 